\title{
He Who Pays the Piper: Shifting Scottish Legal Landscapes
}

\begin{abstract}
If Scotland votes 'Yes' to the question 'Should Scotland be an independent country?' how will its relationship change with the remainder of the UK? A 'yes' vote will have huge financial, political and legal implications. This article, written by Candace Guite, considers the current role of the UK Supreme Court in Scotland, the recent conflict (to which the title alludes) and it reflects on Scotland's potential international status. The UK Government has argued that it would be regarded as the continuator state and an independent Scotland would be a successor state, and so, in the event of a 'yes' vote Scotland would have to re-apply for entry to the European Union and the United Nations. However, there are arguments to support the alternative option, that Scotland could be regarded as a co-equal successor state with England, and thus would retain EU and UN membership.
\end{abstract}

Keywords: legal systems; government; independence; Scotland

\section{BACKGROUND}

The Treaty of Union (22 July 1706), signed by representatives of the separate parliaments of Scotland and England was a recognisably international treaty entered into by two sovereign states. In January 1707 both parliaments passed acts to confirm the Union (Acts of Union 1707) and the Kingdom of Great Britain came into being in May 1707. The Acts of Union also confirmed the independence of Scotland's legal system and court structure. The status of this treaty is considered later when we reflect on what Scotland's position as an independent national state might be following a 'Yes' vote in the forthcoming referendum.

The Scottish Parliament established by the Scotland Act 1998 (hereafter SA 1998) is the preeminent source of law today in Scotland closely followed by the UK parliament, Scottish case law and the European Union. The SA 1998 made a fundamental change to the way in which new law is created for Scotland. But in historical terms the parliament is not new - in Winnie Ewing's opening speech at the first session 12 May 1999, "The Scottish Parliament, which adjourned on 25 March 1707, is hereby re-convened".'

Although the Scottish Parliament exercises devolved power it still has a wide remit to legislate for Scotland in every area except 'reserved matters'. It is still a young parliament but David Steel has praised 'the scale and scope of legislation' achieved comparing it favourably with the pre1999 situation when Scottish interests had to compete with many others in the Westminster Parliament. ${ }^{2}$

As noted above, the Scottish Parliament legislates for all devolved matters but there is a body of UK legislation that either applies directly to Scotland or to Scotland as part of the UK. The 'reserved matters' over which the UK Parliament retained the authority to legislate are in matters that concern the whole of the UK, e.g. foreign affairs and defence.

\section{LEGISLATIVE COMPETENCE AND THE SCOTTISH PARLIAMENT}

In the same momentous year that the Scottish Parliament was re-established the Human Rights Act (hereafter HRA 1998) was passed. This act which is applicable throughout the UK has a clear devolution strand: Tony Blair's preface to the White Paper on the Human Rights Bill commends it for "giving the people of Scotland and Wales more control over their own affairs within the United Kingdom".3 Taken in conjunction, these two acts ensure that legislation passed by the Scottish parliament complies with domestic human rights legislation and UK treaty obligations under the European Convention on Human Rights (hereafter ECHR).

As legislation emanates from both the Edinburgh and Westminster parliaments it is important to have clear definitions and boundaries of responsibility. So within the SA 1998 (s. 29) there is a test of legislative competency, a powerful mechanism for determining the authority of legislation issuing from the Scottish Parliament.

Section 29 (I) of the SA 1998 requires that any act passed by the Scottish Parliament has to meet the test of 'legislative competence' in order to be lawful. Section 29 (2) defines the five conditions or requirements that determine 'legislative competence'. These are: (a) that legislation 


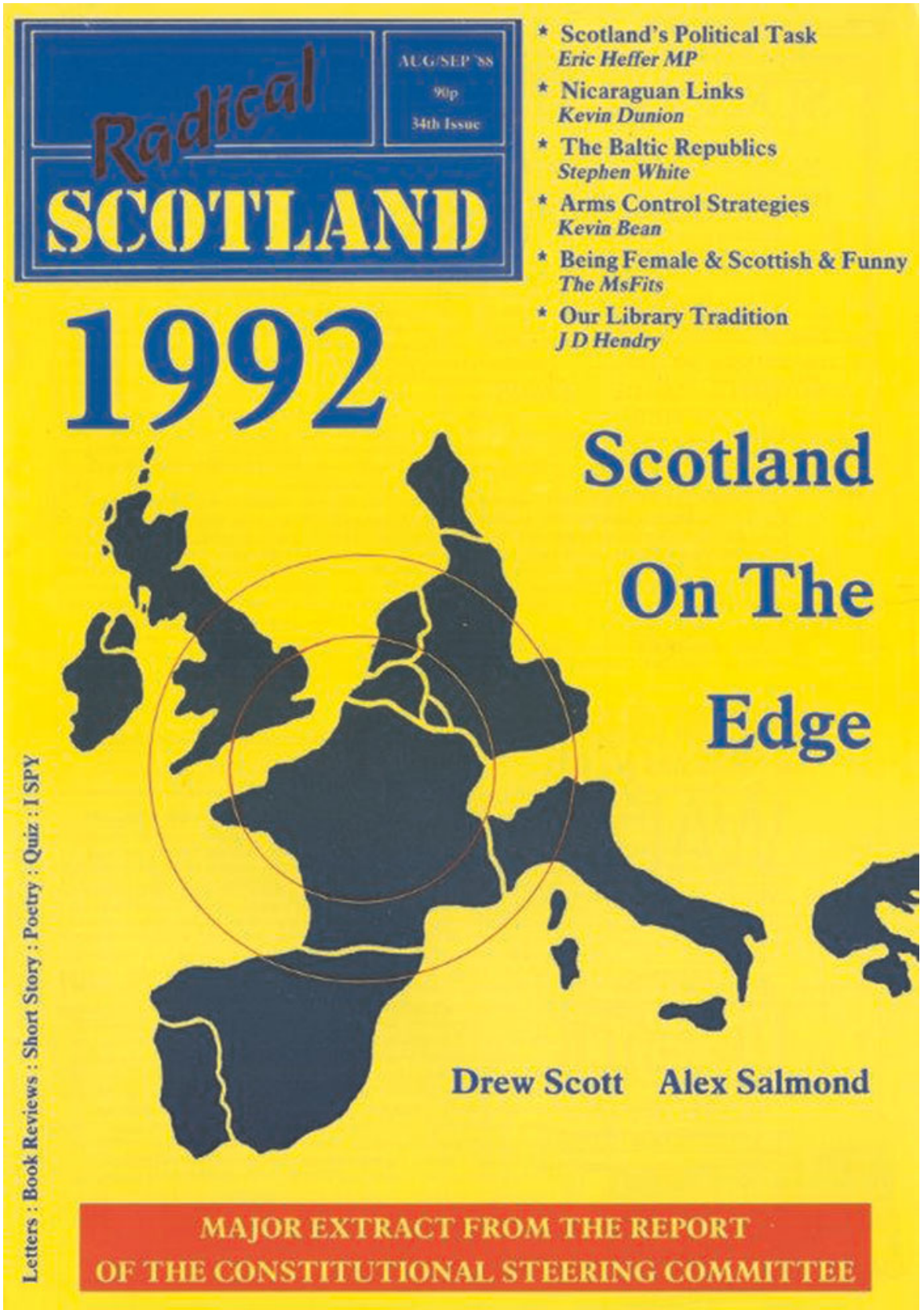

Figure I: Radical Scotland. Cover from the August/September 1988 issue of 'Radical Scotland'. 1992 is a reference to the next general election, and the possibility of a more independent voice for Scotland. The map shows a Scotland remote and 'on the edge', far from the sources of power based in London and Brussels. The vision of the 1988 Constitutional Steering Committee was of a self-governing Scotland within Europe, it remains very close to the SNP's current aspirations. The image (SPA/95/34) is provided courtesy of the Scottish Political Archive, University of Stirling, Stirling FK9 4LA.

must be for Scotland, (b) it cannot trespass on 'reserved matters', (c) it has no authority to alter the historical Acts of Union between England and Scotland, the European Communities Act 1972 and the Human Rights Act 1998, (d) legislation must not conflict with either the ECHR or European Union (EU) law, (e) in order to preserve the separation of powers and so ensure the independence of the judiciary parliament cannot summarily dismiss the Lord Advocate who as well as being a member of the executive has ultimate responsibility for the criminal justice system when exercising the role of Lord Advocate.
The combination of the judicial and executive roles in the person of the Lord Advocate, noted above has raised issues on various grounds about fair and impartial procedure in criminal trials (guaranteed under the ECHR, Article 6). Article 6 upholds the basic human right to a fair trial.

The UK Government, in the person of Lord Wallace of Tankerness, the Advocate General for Scotland also made wide consultations within Scotland (including the Faculty of Advocates and the Scottish Human Rights Commission). This Expert Group reported back in November 2010 to confirm a general consensus that the UK Supreme Court's 
current jurisdiction should be maintained "for reasons of constitutional propriety and, more importantly, to ensure that fundamental rights enshrined in international obligations are secured in a consistent manner for all who claim their protection in the United Kingdom". 4 Surprisingly the Scottish Law Commission, in its evidence to the Expert Group, found no need for such consistency. It is a view very much at odds with the other submissions.

The Expert Group's Report also took care to emphasize that the Supreme Court's role in devolution appeals was strictly to rule on Convention rights. And it recognised the burden placed on Scottish Courts, "the existing arrangements create a very serious problem for the Scottish Court system and the work of the Lord Advocate and Advocate General". ${ }^{5}$

The Scottish Government commissioned its own report (under the chairmanship of Lord McCluskey) to look at devolution appeals from the High Court of Justiciary to the Supreme Court. Their first report was published on 27 June just before the debate on the issue in the Scottish Parliament on 30 June 20II. Their final report was published in September 20II. An action raised in court, on the grounds that rights protected by the ECHR have been infringed, is referred to as a 'devolution issue' because it refers back to the legislative capacity test in s. 29 of the SA 1998.

\section{THE ROLE OF THE UK SUPREME COURT IN SCOTLAND}

Notwithstanding Scotland's separate legal system (preserved under the Acts of Union) there has been a wellestablished civil appeal route from the Court of Session to the UK Supreme Court (the successor body to the House of Lords). Legal and political opinion is very much divided as to the merits of this arrangement. Clearly for the Scottish National Party (SNP) whose primary objective is to achieve an independent Scotland this is less historical anomaly and more an active irritant.

But while Scotland remains a part of the UK there are strong arguments in favour of retaining the current status quo for both civil and devolution appeals. The UK Supreme Court has a developing jurisprudence and expertise in human rights issues now that these can be heard here and not in Strasbourg. There is also a compelling argument that Convention rights should be applied equally and fairly across all parts of the UK.

As the final appellate court for England, Wales, Northern Ireland, and Scotland (civil) the UK Supreme Court has a rich body of case law drawn from these different traditions. Two of its senior members are Scots lawyers and Helena Kennedy makes the point that, "The Scottish lawyers add to the riches of that court, as do the Northern Irish judges, and I think that sometimes you need another stage and another set of thinkers to apply their brilliance to the problem." 6

Kennedy's argument is two pronged: the Scottish representation at the UK Supreme Court is some guarantee that distinctively Scottish aspects of law are understood and taken into account. Her second point is that the prime role of an appellate court is to consider the complex, often fundamental, and often very difficult issues. The Supreme Court provides a final appeal route for the different legal jurisdictions with the UK but Europe is that larger stage, and the European Court the other 'set of thinkers'.

So whether the vote is for or against full independence the ECHR, and the court at Strasbourg will continue to influence the way our law develops. In an independent Scotland, the chief issue surely would be the lengthy time delay Scottish appellants would face in taking a case to Strasbourg. Ideally Scottish citizens would continue to have a direct remedy through appeal to a new Scottish Supreme Court.

This presumes that an independent Scotland would embed the ECHR within a written constitution. It is one of the tenets in Scotland's Future: from the Referendum to Independence and a written constitution. ${ }^{7}$ This publication is a key document for understanding what a new independent Scotland would look like, in terms of its core values, primary objectives and its international outlook.

Is there a price that we pay in Scotland (funding issues aside) for the UK Supreme Court? Are we eroding our autonomy, and loosing some of our distinctive legal tradition by sending cases south of the border? Lord Boyd would argue not; "We have to abide by the highest international standards and if that means that notions of civil and human rights come from elsewhere my view is that it enriches Scottish law rather than diminishes it". 8

\section{THE PIPER: “HE WHO PAYS THE PIPER, AS THEY SAY, CALLS THE TUNE”}

At issue therefore is the role of the UK Supreme Court in hearing 'devolution' appeals from the High Court of Justiciary. Prior to 2009, the Judicial Committee of the Privy Council (to which the UK Supreme Court is the successor body) would have heard these appeals.

The High Court of Justiciary is Scotland's highest criminal court hearing the most serious cases at first instance, and it acts as the final appeal court for all criminal offences. Therefore the appeals from this court to the UK Supreme Court only arose in connection with the provisions of the SA 1998 s. 57 (2). Section 57 (2) was designed to prevent the Scottish Executive enacting legislation or committing an act that is incompatible with Convention rights. Devolution appeals typically concern the potential breach of Article 6 of the European Convention on Human Rights (ECHR). From a total of 969 devolution issues served on the Lord Advocate between 20 May 1999 and 20 May 2000, 824 alleged breach of Article 6.9

The two particularly high profile cases to be referred to the UK Supreme Court were Fraser (Nat Gordon) v HM Advocate [20II] UKSC 2 and Cadder 
(Peter) v HM Advocate [2010] UKSC 43. In the Cadder case the Supreme Court, following Salduz ruled that admissions made by Peter Cadder whilst in police custody and without the benefit of legal advice were incompatible with his Convention rights under Article 6 (I) and 6 (3)(c).

Salduz v Turkey (2009) 49 E.H.R.R. was decided on 27 November 2008, and held that suspects in detention must as a rule have access to legal advice. The UK Supreme Court held that the phrase used in the European ruling "as a rule" was intended to apply equally to all states (and all parts of the UK) accepting the Convention. The Cadder case caused a major upheaval in Scotland with a large number of other cases in waiting affected by the decision ( 867 cases were abandoned). But it has been pointed out by critics such as Tony Kelly and Niall McCluskey that the Scottish Parliament could have been much more proactive and responded to the Salduz judgment when it was first issued. Professor Tony Kelly commented, "A Convention compatible Scottish criminal justice system would be left entirely intact"10 and advocate Niall McCluskey blamed the upheaval on the "failure of the Scottish parliament to legislate when the Salduz decision came in..."।

In Fraser the Supreme Court ruled that Nat Fraser's Convention right (Article 6) had been compromised by the withholding of evidence at the earlier trial thus overturning the High Court of Justiciary's decision. The case was remitted back to Scotland for a retrial, and formed the subject of a Channel 4 documentary. ${ }^{12}$ The UK Supreme Court ruling was based on Convention compatibility, and as such clearly within their jurisdiction.

The First Minister Alex Salmond and his Justice Secretary Kenny MacAskill denounced the Fraser ruling as undue interference in the Scottish court system. MacAskill's direct threat to withdraw Scottish funding for the UK Supreme Court (made in the course of a speech to police superintendents) was widely interpreted as a threat to judicial independence and the due 'rule of law'. ${ }^{3}$

The threat proved to be a political flashpoint not just within the Scottish Parliament but also crucially between Scottish ministers and senior members of the Scottish legal profession. First Minister Alex Salmond's potentially libelous slur on human-rights lawyer Tony Kelly further inflamed the situation. Salmond said of Kelly - he, "believes that the judicial system is there to serve their interest and make sure they can make an incredibly comfortable living by trailing around the prison cells and other establishments of Scotland trying to find what might be construed as a breach of human rights of an unlimited liability back to $1999{ }^{\prime \prime}{ }^{14}$

The personal nature of the slur prompted a swift and public rebuke in the form of an open letter signed by the Presidents of the Glasgow and Edinburgh Bar Associations - the letter concluded, "The First Minister's comments are unprecedented and should be withdrawn. Such remarks amount to a challenge to the independence of the entire Scottish legal profession". ${ }^{5}$ The debate over the role of the UK Supreme Court in Scotland is far from over, and it does raise some concern about the future protection of human rights in Scotland.

\section{HUMAN RIGHTS}

At times the interest of 'the state' and the 'human rights' of the individual may be in opposition to each other. Are the mechanisms and controls currently in place sufficient to guarantee human rights? How should conflicts between rights be resolved? The HRA 1998 upholds and guarantees the rights of an individual even when this conflicts with the views of the majority of the population. Both Westminster and Holyrood governments have at times taken issue with human rights decisions that have gone against them.

But both the Westminster and Edinburgh parliaments need to work within the overarching context of the UK's treaty obligations under the ECHR. The expressed purpose of the HRA 1998 was "to bring those rights home", to make Convention rights enforceable in British courts.

The hope and the expectation was that this would raise awareness of human rights issues in wider society and within the parliament. Specifically it would, "lead to closer scrutiny of the human rights implications of new legislation and new policies". 16

Hiebert has raised important concerns about the effectiveness of the Joint Committee on Human Rights (JCHR) role in scrutinizing legislation emanating from the Westminster parliament, "By the time the JCHR reports, the minister and cabinet will have already consulted their advisors, reached their decision, and are extremely reluctant to revisit this judgment". ${ }^{17}$

But arguably the mechanisms in place in the Scottish Parliament (SA 1998 s. 29) have proved much more effective in active shaping of the law to meet the higher requirements of the ECHR than its Westminster counterpart. It is evident that in devolved legislation relating to children, e.g. the Children's Hearings Act 2010, that the impetus for change, and the guiding principles adopted derive directly from the ECHR.

Devolution and human rights legislation have changed both the context and substance of the Scottish legal process. The important role of the Scottish Human Rights Commission in raising awareness of human rights issues and promoting human rights must further expand and develop. Whichever way the 2014 vote goes the Commission should continue to play its crucially impartial role to ensure that human rights considerations continue to shape law in Scotland today from legislative process to judicial interpretation.

\section{THE SCOTLAND ACT 2012}

The new Scotland Act 2012 (hereafter SA 20I2) makes a number of important changes to the SA 1998 and to the 
Criminal Procedure (Scotland) 1995 Act (hereafter CPSA 1995). The SA 2012 implements many of the recommendations of the Calman Commission whose final report Serving Scotland better: Scotland and the United Kingdom in the $2 I^{\text {st }}$ century was published in $2009 .{ }^{18}$ Its very title makes clear the UK government's desire to retain Scotland as part of the UK. The Act extends significant new powers to the Scottish Parliament, for example, the right to raise taxes, and to administer its own electoral procedures.

To some extent SA 2012 meets the recommendations of the McCluskey Report. This was an expert group commissioned by the Scottish Government to review the Supreme Court's jurisdiction in Scottish criminal cases. ${ }^{19}$ One issue that the new Act has resolved is the unlimited liability for human rights violations back to the start of the Scottish Parliament in 1999. Section 14 introduces a time limit for claims that a minister has acted incompatibly with Convention rights. This brings it into line with the I2-month time limit for actions under the HRA 1998.

Section 34, SA 2012 concerns the role of the Advocate General in relation to criminal proceedings. It amends the CPSA 1995 introducing "compatibility issues". Compatibility issues arise when it is claimed that a public authority (this includes courts) has contravened Convention rights or EU law. Compatibility here refers to breaches or incompatibility with EU law or with the rights guaranteed under the HRA 1998 and can only be raised in the course of criminal proceedings.

\section{A SUPREME COURT FOR SCOTLAND?}

An independent Scotland would need its own Supreme Court but it could choose to send human rights cases to Strasbourg. Alex Salmond has argued that the Strasbourg court has a wider understanding of the differences between legal systems and in principle therefore would take a more balanced and pragmatic approach, "... if we are to be scrutinised in terms of the overall scrutiny then let it be by the court that scrutinises another 47 jurisdictions and not by the Supreme Court in England". ${ }^{20}$

An autonomous Scottish Supreme Court is the first of six possible models considered in the Walker report commissioned by the Scottish Government, and is the only one considered here. ${ }^{21}$ Model One has two variations. The first variation is the self-contained legal system comprising civil, criminal and constitutional jurisdictions. The new Supreme Court would either form the apex court for all these jurisdictions or alternatively constitutional issues could be referred to a separate Constitutional Court.

It would be an important matter of choice as to whether the new Supreme Court formed a tier above Scotland's College of Justice. The College of Justice comprises the Court of Session (civil) and the High Court of Justiciary (criminal). If a new Supreme Court was to merge with the College of Justice this would require additional tiers, or alternatively larger courts convened with members drawn from the senior judiciary.

Walker points to the examples of Ireland (1920) and New Zealand (2003) who developed their own complex autonomous systems. Ireland has an integrated Supreme Court but when it hears constitutional issues the Constitution stipulates that it must sit with a minimum of five senior members of the judiciary. "There would be clear advantages in drawing a similar internal procedural division within the structure of any future Scottish Supreme Court".22

Walker speculated that it was highly probable that an independent Scotland would develop a written Constitution. And indeed it forms a central part of the key paper discussed earlier Scotland's Future: from the Referendum to Independence and a Written Constitution. ${ }^{23}$

The SNP believes that a written constitution, in contrast to Westminster's unwritten constitution, offers better safeguards for individual freedoms and as a check on the power of the executive. The paper sets in place a timescale and plan. If Scotland votes Yes in 2014, the final transfer of power from Westminster to Edinburgh takes place by March 2016, and elections for the new parliament would follow in May 2016.

It would be the responsibility of this new parliament to convene a constitutional convention. Drafting the new written constitution is envisaged as a highly participative, citizen-led process. The paper points to recent examples in British Columbia (2004), the Netherlands (2006), Iceland (2010) and Ireland (20I2). In particular, the Icelandic experience (using social media to allow citizens to engage with the draft constitution) is commented upon.

The second variation (Model One) sees Scotland as the final appellate court for both criminal and civil matters but constitutional cases would be referred to the UK Supreme Court. It seems very unlikely that this option would command political support in the event of a Yes vote.

\section{THE ROLE OF THE SCOTTISH LAW COMMISSION}

The Scottish Law Commission would play a crucial role in ensuring that Scottish law continued to develop in response to changing needs - particularly so if Scotland chooses independence. "The work of a law reform agency is very important in smaller jurisdictions because, owing to the limited number of cases that come to court, it is difficult to achieve extensive judicial development of the law."24

The work of the Scottish Law Commission (whose current remit covers both reserved and devolved matters) might expand to support this. At present because of pressures of time the main focus is on devolved matters. As well as collaborative projects with its English and Northern Ireland counterparts the Scottish Law Commission (SLC) draws inspiration from much further afield. As James Young, Chairman put it in 


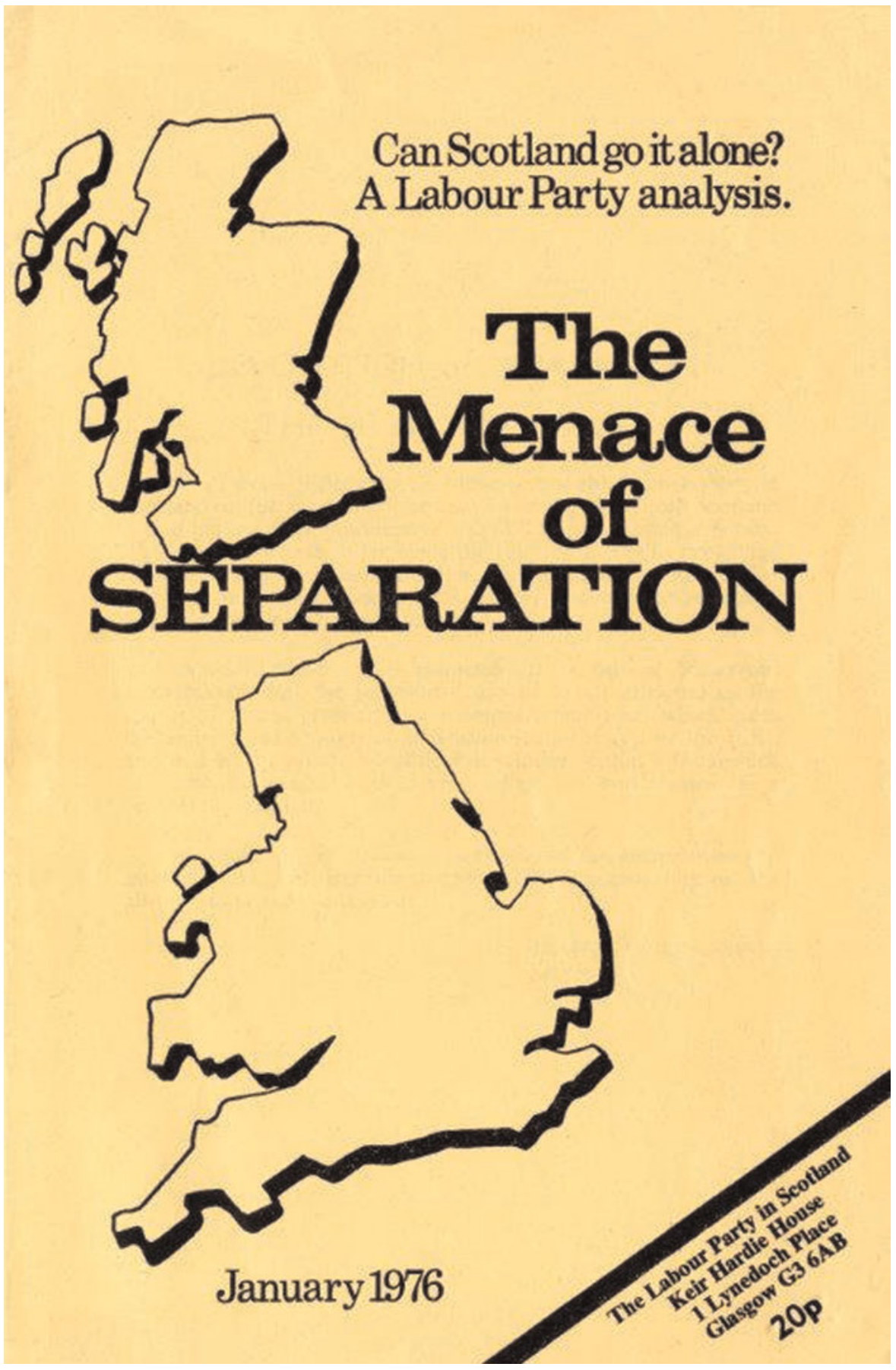

Figure 2: A campaign leaflet from the Labour Party in Scotland, 1976 shows an independent Scotland cut adrift and isolated. The warning message is strikingly similar to the current coalition's 'Better Together' campaign which argues that Scotland can have a distinctive voice within the UK and benefit from a single currency, and a powerful international voice. This image (SPA/ GR/46.2) is provided courtesy of the Scottish Political Archive, University of Stirling, Stirling FK9 4LA.

his foreword of the Commission's 20II annual report, "At one time 'comparative law' in Scotland largely consisted of looking at English law and adapting it, but now we range much more widely". 25

The Scottish Law Commission also recognises that Scotland needs to attract business, investment and opportunity and to achieve this the Scottish law must adapt and meet new challenges. Business is conducted across borders, and a large part of that now is electronic. The Commission set up a project in 2010 to review contract law within the Draft Common Frame of Reference: Principles, Definitions and Model Rules of European Private Law. ${ }^{26}$ The Commission's work on the electronic conduct of contracts reported in the $20 \mathrm{II}$ annual report provides a good example of developing the law to meet changing business needs. 


\section{AN INTERNATIONAL STATE?}

An independent Scotland would exercise complete financial and legal autonomy, and so could call the tune. Scotland's wealth in natural resources (off-shore oil) is a key element in the Scottish National Party's (SNP) bid for independence. ${ }^{27}$ But the future landscapes, political, geographical and legal are fluid. It seems that constitutional change can open a Pandora's box. Scotland after all has many distinct geographic and cultural regions.

Many of those essential oil resources are based in Shetland, and perhaps the last thing the First Minister expected to deal with in the lead-up to the Referendum was a call for home rule from the Shetland Islanders. ${ }^{28}$ Shetland Island Council already exercises a considerable degree of autonomy within Scotland. It is now actively looking at possible future constitutional models that would safeguard and perhaps enhance its current autonomy. ${ }^{29}$

The Crown Dependencies of the Bailiwick of Jersey, the Bailiwick of Guernsey and the Isle of Man provide one such exemplar. These islands are not part of the UK and produce their own primary and secondary legislation. The Queen is Head of State of each, the constitutional link being directly through the Crown. Although as territories of the UK, they are currently subject to whatever international agreements, conventions and treaties to which the UK government is a signatory. ${ }^{30}$

The 2014 Referendum will give the people of Scotland the opportunity to decide if Scotland should be an independent country. If Scotland answers 'Yes' it will lead to momentous change for Scotland in its relationship with the remainder of the UK (rUK) and with Europe and the international community more generally.

The Deputy First Minister Nicola Sturgeon's foreword to Scotland's future sees Scotland as, "a thriving and successful European country ... participating fully in Europe and the community of nations, on the basis of equality, responsibility and friendship." 3 I The vision is very clear, and the argument for the right to self-determination is very persuasive. What is unclear though is precisely what Scotland's international legal status would be following a 'Yes' vote.

The UK Government (the Foreign and Commonwealth Office, the Cabinet Office and the Office of the Advocate General) instructed Professor James Crawford and Professor Alan Boyle to advise on the legal status of rUK and Scotland following independence. ${ }^{32}$ In particular, Crawford and Boyle were asked to comment on (a) the likelihood that rUK would be regarded as the continuator state in international law and (b) to assess what rUK and Scotland's respective positions would be in relation to the European Union and other international organisations.

To date Crawford and Boyle's Opinion offers the most detailed and substantive analysis of Scotland's potential legal status in international law following independence. States are legal entities in international law with the capacity to enter into treaty with other states. For example, when Scotland entered into the Treaty of Union in 1706 with England it did so as an autonomous

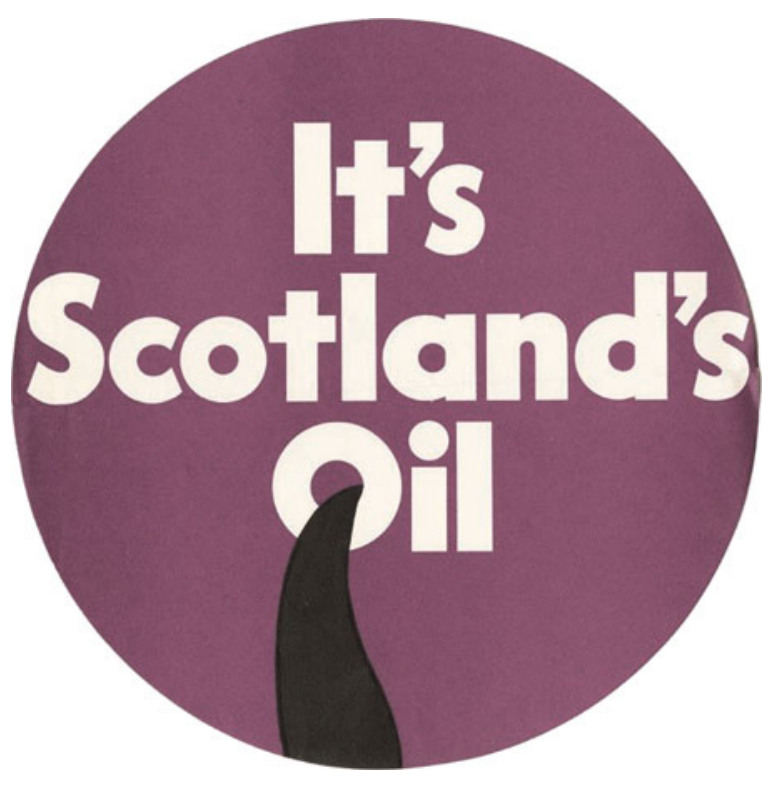

Figure 3: Scotland's Oil: The SNP's campaign to keep a larger share of Scotland's offshore oil was launched in September 1972. This image (SPA/76I/4)c. 1973 is provided courtesy of the Scottish Political Archive, University of Stirling, Stirling FK9 4LA.

sovereign state but Crawford and Boyle's argue the treaty has no present international status. ${ }^{33}$

In international law certain questions have to be settled when part of an existing sovereign state either secedes (secedes implies this is by unilateral means) or achieves 'negotiated independence' (to use Crawford and Boyle's preferred term) from the original state. Clearly in relation to Scotland we are speaking of negotiated independence following the agreement of both governments to work together to achieve a fair and democratic outcome to the 2014 referendum. ${ }^{34}$

Crawford and Boyle discuss three possible options in relation to Scotland and the UK in order of likely probability. The first option is that $r U K$ is regarded in international law as the continuator state and Scotland is the successor state. 'Continuator states' retain the legal identity (including all treaty obligations and membership of international organisations) of the pre-existing state. International recognition of claim to be the continuator state takes into account a number of conditions and factors. Principally, but not exclusively, the claim to be the continuator state is based on the retention of the majority of territory and population.

'Successor states' are completely new international entities and usually have to apply for membership of international organisations. The second option is that two new successor states would emerge and treaty obligations and membership of international organisations would be a matter of negotiation. This would be a good option for Scotland but rUK would need to agree to it. The third option considered is whether Scotland could re-affirm its identity with the pre- 1707 state. But Crawford and Boyle argue that this would not affect the presumption that rUK would be recognized as the continuator state. 
In comments on the nature of the 1707 Union, specifically whether a new state was created (the Kingdom of Great Britain) or if England remained the continuator state, Crawford and Boyle rather summarily dismiss the issue "Whether or not England was also extinguished by the union, Scotland certainly was extinguished as a matter of international law, by merger either into an enlarged and renamed England or into an entirely new state". ${ }^{35}$

But what about equity and the right of the Scottish people to self-determination? Is it so obvious and straightforward that having entered into the 1706 treaty as equal partner and sovereign state that Scotland now comes away with nothing (the first option, one continuator state and one successor state)?

Professor David Scheffer has argued that whilst clearly rUK has the larger population "the fundamental premise of Scottish independence is to regain the sovereignty of pre-1707". ${ }^{36}$ This leads in Scheffer's view to the two successor states option - "the break-up should be viewed as two Successor states of equal legitimacy - not size, wealth, or power, but legitimacy". ${ }^{37}$

In relation to membership of the EU, Crawford and Boyle believe that Scotland as successor state would have to apply for membership. Citing the examples of France and Denmark (whose population and size underwent change without jeopardising their membership of the EC), they posit that rUK "will simply continue the UK's membership of the Council of Europe". ${ }^{38}$ But Crawford and Boyle do make some allowance for the view that individual citizenship of the EU confers some rights which the European Court of Justice is likely to find persuasive. ${ }^{39}$

Professor Scheffer's rather more pragmatic and sceptical approach - "International law will inform every step of the way, but political negotiations and diplomacy will dictate the outcome" has opened up the debate about possible future outcomes following the 2014 Referendum.

\section{CONCLUSION}

On 23 January 2013 the Scottish Law Librarians Group met for a New Year gathering at the Society of Solicitors Library in the Supreme Courts of Scotland in Parliament Square, Edinburgh ( 2013 being the $25^{\text {th }}$ anniversary year of the group). The occasion was a fun/serious networking event. Scottish law librarians represent all sectors of the profession from academic, to law firm, to government and parliament.

We divided into groups, and each group was assigned five questions to think about, after fairly short intervals (this was a net-working event!) people swapped tables. The most interesting question on the list from my point of view was no. 4. "How do you think a yes vote in the independence referendum will change the nature of law in Scotland and our role as law librarians?"

I had just happened to catch an interview on BBC Radio Scotland with David Scheffer sometime earlier that month, and become intrigued with the issue, partly because he appeared to be offering an alternative view to the status quo assumption. The consensus on my table was that if Scotland votes yes, our role will certainly become more varied and challenging as we respond to the changing situation.

Which way the vote will go is hard to predict. But perhaps as never before Scotland's citizens now have greater access to the accumulating documentation on UK Government, Scottish Government and independent websites. ${ }^{40}$ The debate is certainly very well informed.

\section{Footnotes}

'Megaughin, E. and Jeffery, C. (2009) Introduction: the first decade in perspective, The Scottish Parliament 1999-2009: the first decade, edited by Charlie Jeffery and James Mitchell, Edinburgh, Luath Press in association with Hansard Society Scotland, p. 9.

${ }^{2}$ Steel, D. (2009) A dozen differences in devolution, The Scottish Parliament 1999-2009: the first decade, edited by Charlie Jeffery and James Mitchell, Edinburgh, Luath Press in association with Hansard Society Scotland, 15-19.

${ }^{3}$ Great Britain. Home Office (1997) Rights brought home: the Human Rights Bill. Cm. 3782.

${ }^{4}$ Great Britain. Office of the Advocate General for Scotland (2010) Expert Group (Chairman, David Edward) Section 57(2) and Schedule 6 of the Scotland Act 1998 and the Role of the Lord Advocate: Report of the expert group appointed by the Advocate General for Scotland I-27, 19 [Online]. Available at: https://www.gov.uk/government/consultations/devolution-acts-and-issues-of-thelord-advocate.

${ }^{5}$ Ibid. 15.

${ }^{6}$ Rhodes, M. (20II) Freedom Fighter. Holyrood 258 (27 June 20I I), 14-17, 17.

${ }^{7}$ Scottish Government (2013) Scotland's future: from the referendum to independence and a written constitution Section 2.14 [Online] Available at: http://www.scotland.gov.uk/Publications/2013/02/8079/0.

${ }^{8}$ Reid, R. Supreme Court Holyrood 257 5I-53, 52.

${ }^{9}$ Killen, F. ECHR Incorporation into domestic law: the Human Rights Act 1998 and the Scotland Act 1998 Scottish Parliament (Information Centre) Research Paper 0I/03 I5 January 200122.

${ }^{10}$ Kelly, T. (20II) Expert Group: devolution jurisdiction and the Supreme Court Scots Law Times 159-163, 162.

II Reid, R. Supreme Court Holyrood 257 5I-53, 53.

12 Graff, V. (2013) The Murder Trial Radio Times 6-12 July 2013 26-27. 
${ }^{13}$ The Scotsman, 6 February 20II. The comments related to Scotland's $£ 500,000$ annual share of the Supreme Court's running costs "I am not paying money that would come out of the police budget, or prison budget or community payback budget because they are routinely taking cases that we as a country do not think should be going there "He who pays the piper, as they say, calls the tune".

${ }^{14}$ Rhodes, M. (20II) The Eck's factor. Holyrood 257 (I3 June 20I la), 16-22, 20.

${ }^{15}$ Waddell, K. and Henry, G. (20II) [Letter of support for Tony Kelly following a personalized attack by the First Minister], Herald $16^{\text {th }}$ June 2011, p. 16.

${ }^{16}$ Great Britain. Home Office (1997) Rights brought home: the Human Rights Bill Cm. 3782 I.I8

${ }^{17}$ Hiebert, J. (2012) Governing under the Human Rights Act: the limitations of wishful thinking. Public Law, 2012 (January) 39-40.

${ }^{18}$ Great Britain (Commission on Scottish Devolution), Serving Scotland Better: Scotland and the United Kingdom in the $2 I^{\text {st }}$ Century. Edinburgh, Commission on Scottish Devolution, 2009.

${ }^{19}$ Scottish Government (201I) Review Group (Chair: John McCluskey) Examination of the relationship between the High Court of Justiciary and the Supreme Court in criminal cases. Edinburgh, 2011.

${ }^{20}$ Rhodes, M. (20II) The Eck's factor. Holyrood 257 (13 June 20I Ib), 16-22, 20.

${ }^{21}$ Scottish Government (2010) Walker Report Final appellate jurisdiction in the Scottish legal system Edinburgh, Legal System Division, 2010 [Online] Available at: http://www.scotland.gov.uk/Publications/2010/01/19/548।3/0.

${ }^{22}$ Ibid. 66.

${ }^{23}$ Scottish Government (2013) Scotland's future: from the referendum to independence and a written constitution I-16 [Online] Available at: http://www.scotland.gov.uk/Publications/2013/02/8079/0.

${ }^{24}$ Scottish Law Commission, Annual Report 20II, No. 225 Edinburgh, The Stationery Office, 2012, I-40, 8.

25 Ibid. 7.

${ }^{26}$ Scottish Law Commission (20II) Review of contract law: Discussion paper on interpretation of contract (Discussion Paper 147) Edinburgh, The Stationery Office.

${ }^{27}$ Scottish Government (2007) Choosing Scotland's future: A national conversation: Independence and responsibility in the modern world Section 2 (17) [Online]. Available at: http://www.scotland.gov.uk/Publications/2007/08//3/03747/0.

${ }^{28}$ Peterkin, T. Shetland and Orkney bid for home rule. Scotland on Sunday, 17 March 20I3, I, 4.

${ }^{29}$ Shetland Islands Council (Chief Executive), Constitutional Reform, Report No. CE-0I-F, 24 April 2013.

${ }^{30}$ UK Government (Ministry of Justice), Fact Sheet on the UK's relationship with the Crown Dependencies, https://www.gov.uk/ government/uploads/system/uploads/attachment_data/file/I85870/crown-dependencies.pdf.

${ }^{31}$ Scottish Government (2013) Scotland's future: from the referendum to independence and a written constitution I-16 2 [Online] Available at: http://www.scotland.gov.uk/Publications/2013/02/8079/0.

${ }^{32}$ Crawford, J. and Boyle, A. (2013) 'Annex A Opinion: Referendum on the Independence of Scotland-International Law Aspects' in Scotland Analysis: Devolution and the implications of Scottish Independence 67-II2 (Cm 8554:2013) [Online] Available at: https://www.gov.uk/government/publications/scotland-analysis-devolution-and-the-implications-of-scottish-independence.

33 ibid para. 40-46.

${ }^{34}$ http://www.scotland.gov.uk/About/Government/concordats/Referendum-on-independence.

${ }^{35}$ Crawford, J. and Boyle, A. (2013) 'Annex A Opinion: Referendum on the Independence of Scotland-International Law Aspects' in Scotland Analysis: Devolution and the implications of Scottish Independence 67-II2 para 37 (Cm 8554:20 I3) [Online] Available at: https://www.gov.uk/government/publications/scotland-analysis-devolution-and-the-implications-of-scottish-independence.

${ }^{36}$ Scheffer, D. (2013) International political and legal implications of Scottish independence Working Papers Series 2013:0I I-2I (Adam Smith Research Foundation, University of Glasgow).

${ }^{37}$ Ibid. 9.

${ }^{38}$ Crawford, J. and Boyle, A. (2013) 'Annex A Opinion: Referendum on the Independence of Scotland-International Law Aspects' in Scotland Analysis: Devolution and the implications of Scottish Independence 67-II2 para I46 (Cm 8554:20I3) [Online] Available at: https://www.gov.uk/government/publications/scotland-analysis-devolution-and-the-implications-of-scottishindependence.

${ }^{39}$ lbid para. 171.

${ }^{40}$ This is not to ignore the effect of the digital divide in Scotland. Much of the official documentation, the campaign literature, and other material is available in print. The images in this article are courtesy of the Scottish Political Archive at the University of Stirling www.scottishpoliticalarchive.org.uk and my thanks are due to Sarah Bromage. The Scottish Political Archive has a rich collection of print, visual material, and oral recordings, and is actively collecting material based around the forthcoming referendum.

\section{Biography}

Candace Guite is the Senior Subject Librarian for law at the University of Stirling. 